\title{
FEED-IN TARIFF, AUCTIONS AND RENEWABLE ENERGY SCHEMES IN MALAYSIA: LESSONS FROM OTHER JURISDICTIONS*
}

\author{
Farahdilah Ghazali** \\ Abdul Haseeb Ansari*** \\ Maizatun Mustafa**** \\ Wan Mohd Zulhafiz Wan Zahari****
}

\begin{abstract}
Malaysia introduced Feed-in Tariff (FiT) in 2004 to incentivise renewable energy projects through the implementation of the National Renewable Energy Policy and Action Plan 2009 and the Renewable Energy Act 2011 (Act 725). Nevertheless, this FiT system failed to assist the country in increasing electricity generation from renewable sources. Later, auctions were introduced to boost the renewable shares, particularly solar photovoltaic power generation, after the quota for solar under the FiT were taken up. The tenders incorporated standard form of the contract along with a long-term Power Purchase Agreements (PPA) which induced for the lowest price for power generation and guaranteed access to the national grid. This measure is considered as an excellent instrument to expand the renewable energy sector. There has always been a question: whether abandoning FiT for auctions is a feasible choice in the interest of sustainable clean energy for sustainable development? The main objective of the present article is to investigate the implementation of auctions to support renewable energy development in
\end{abstract}

* This paper is funded by the Fundamental Research Grant Scheme (FRGS), granted by Ministry of Education under the Project ID: RACER/1/2019/SSI10/UIAM//2.

** Lecturer, Institute of Oceanography and Environment, Universiti Malaysia Terengganu. Email: farahdilah.g@umt.edu.my .

*** Professor, Ahmad Ibrahim Kulliyyah of Laws, International Islamic University Malaysia. Email: ahaseeb@iium.edu.my.

${ }^{* * * *}$ Associate Professor, Ahmad Ibrahim Kulliyyah of Laws, International Islamic University Malaysia. Email: maizatun@iium.edu.my.

*****Assistant Professor, Ahmad Ibrahim Kulliyyah of Laws, International Islamic University Malaysia. Email: wzulhafiz@iium.edu.my.

[Received: 6 August2019, Accepted: 2 April 2020, Published: 30 June 2020] 
Malaysia and to examine whether auctions could replace FiT. This study adopted a doctrinal and comparative approach. It concluded that competitive bidding is preferable to support mature technology and large-scale generations, while FiT should be sustained to support new technologies. The article has also identified several countries such as Germany and India, who have successfully implemented competitive bidding systems to support the aspiration to expand the renewable energy sector.

Keyword: Renewable energy policy, FiT, auctions, support scheme, economics instrument

\title{
TARIF GALAKAN, SKIMA BIDAAN DAN SKIM TENAGA BOLEH BAHARU DI MALAYSIA: PANDUAN DARI BIDANGKUASA YANG BERBEZA
}

\begin{abstract}
ABSTRAK
Malaysia telah memperkenalkan Tarif Galakan (FiT) pada tahun 2004 untuk memberi insentif kepada projek tenaga boleh baharu melalui pelaksanaan Dasar dan Pelan Tindakan Tenaga Diperbaharui Nasional 2009 dan Akta Tenaga Boleh Baharu 2011 (Akta 725). Walaupun bagaimanapun sistem FiT ini tidak berjaya membantu negara untuk meningkatkan penjanaan tenaga letrik daripada sumber tenaga boleh baharu. Kemudian, sistem bidaan diperkenalkan untuk meningkatkan kadar penjanaan tenaga boleh baharu, terutamanya daripada tenaga suria fotovoltaik (PV) selepas kehabisan kuota untuk suria PV di bawah FiT. Tender-tender ini telah menggabungkan beberapa kontrak standad bersama dengan Perjanjian Pembelian Kuasa jangka panjang yang menjamin harga terendah bagi penjanaan kuasa dan akses ke grid nasional. Langkah ini dianggap sebagai instrumen yang dapat menggalakkan perkembangkan sektor tenaga boleh baharu. Persoalan yang selalu timbul adalah: sama ada wajar untuk menggantikan FiT dengan sistem bidaan untuk kepentingan tenaga bersih dan lestari bagi mendukung pembangunan mampan? Objektif utama makalah ini ialah untuk menyiasat perlaksanaan sistem bidaan bagi mendukung pembangunan tenaga boleh baharu di Malaysia dan untuk mengkaji sama ada FiT boleh digantikan dengan sistem bidaan. Makalah ini menggunakan pendekatan doktrinal dan perbandingan. Ia menyimpulkan bahawa system bidaan lebih sesuai untuk menyokong teknologi yang telah matang dan generasi berskala besar sementara FiT harus diteruskan untuk membantu teknologi baru. Makalah ini juga telah mengenal pasti beberapa negara seperti Jerman dan India, yang telah
\end{abstract}


berjaya mengakpliasikan sistem bidaan kompetitif bagi mendukung hasrat untuk memajukan sektor tenaga boleh baharu.

Kata kunci: Dasar tenaga boleh baharu, FiT, bidaan, skim sokongan, instrumen ekonomi

\section{INTRODUCTION}

Development of renewable energy (hereinafter referred to as RE) support schemes are vital to increase RE share in the national energy mix. Many international discussions have been conducted to determine the appropriate system to achieve these targets. ${ }^{1}$ The importance of RE sources was not sufficient to promulgate an effective energy policy. ${ }^{2}$ Effective policies on RE are indispensable to provide schemes and incentives which aligned with sustainable development goals (SDGs). In response to the challenges in exploitation and generation of RE in the electricity sector, numerous regulatory policies and laws have been designed and implemented.

Globally, there are four main commercial schemes which have been designed and implemented for RE generation and implementation. The schemes are the Feed-in Tariff (hereinafter referred as "FiT"), renewable portfolio standards (RPS), tendering system or auctions and net energy metering. Many countries implement more than one policy to support the growth of the RE sector. In contrast, some others consistently review their existing policies, and where necessary replaced with the new one to correspond with their national objectives and targets. Since RE technology is often expensive than fossil fuels, it is crucial to determine who should pay for the extra costs of RE generation. The cost advantage is a crucial factor for investors to consider in the RE policy. For instance, policies should induce investment; either through technological push or pull factors in

1 Toby D. Couture, David Jacobs, Wilson Rickerson, and Victoria Healey. Next Generation of Renewable Electricity Policy: How Rapid Change is Breaking Down Conventional Policy Categories. No. NREL/TP-7A4063149. National Renewable Energy Lab.(NREL), Golden, CO (United States), 2015, 1.

2 Jay Apt, Lester B. Lave, and Sompop Pattanariyankool. "A national renewable portfolio standard? Not practical." Issues in Science and Technology 25, no. 1 (2008): 54. 
the market. Government demonstration grants, public R\&D, grants for small and medium-sized enterprises (SMEs), and investment subsidies are the top four of technological push policies which investors perceive to be effective. ${ }^{3}$ Therefore, the government is expected to analyse which of the policies suits the RE targets in line with other local circumstances.

The first part of this article elaborates on the implementation of FiT in Malaysia as the main component under the Renewable Energy Act 2011. This was done to accelerate the development of RE and increase $\mathrm{RE}$ contribution in the national energy mix. The article also discusses the implementation of auctions in Malaysia as well as other countries, including Germany and India. This article adopts a doctrinal approach with analysis of related laws and regulations, as well as some components of comparative study of various policy combinations in the development of RE generation in other jurisdictions.

\section{FEED-IN TARIFF TO SUPPORT RENEWABLE ENERGY DEVELOPMENT}

The FiT is a price-based mechanism to encourage RE generation and provides a guarantee of payments per kilowatt-hour for a specified period. ${ }^{4}$ The European Commission has acknowledged this scheme as the most effective and efficient measure to support RE generation. ${ }^{5}$ The FiT system has been implemented in many jurisdictions and has spurred the energy sector with tremendous contributions in dealing with carbon reduction, market expansion, and employment as well as energy security. ${ }^{6}$ This scheme has shown enormous positive outcomes

3 Mary Jean Bürer and Rolf Wüstenhagen, "Which Renewable Energy Policy is a Venture Capitalists Best Friend? Empirical Evidence from a Survey of International Cleantech Investors," Energy Policy 37, no. 12 (2009): 50015002.

4 Guaranteed duration period is generally for 10 to 20 years.

5 Proposal for a Directive of the European Parliament and the Council on the promotion of the use of energy from Renewable Sources (Brussels, European Commission, 2016).

6 Miguel Mendonca. Feed-in Tariffs Accelerating the Deployment of Renewable Energy, (London: Earthscan/ World Future Council, 2007), 2527. 
in supporting $\mathrm{RE}$ deployment in Europe. ${ }^{78}$ Approximately 110 countries have adopted the FiT system by the end of $2015 .{ }^{9}$ There have been several FiT models ${ }^{10}$ implemented in various jurisdictions. The RE investors preferred the FiT over carbon trading, carbon tax, and RPS. ${ }^{11}$ The FiT system undeniably plays a significant role in establishing RE markets in Malaysia. A study has adumbrated several factors that have determined the effectiveness of FiT, including infrastructural, social, economic, governance and market factors. ${ }^{12}$

A wide range of RE support schemes is needed to lower risks associated with RE technologies and to encourage competition with the conventional ones. The difficulty in tariff regime for RE poses legal risk for RE investors and policymakers. In the Spanish case of Eiser Infrastructure Limited and Energia Solar Luxembourg Sarl v Kingdom of Spain $^{13}$ it was shown that the laws and policies introduced by the

7 Many European countries suggest that FiT leads to tremendous RE penetration at a lower cost. This scheme was found to be effective in promoting wind energy, biogas and photovoltaic technologies. Other fiscal incentives (tax exemptions or reductions) are used to support FiT or other main mechanisms such as quota obligations and tendering system. However, the effectiveness of fiscal incentives like tax exemptions is hardly measured as they are only meant to support the primary mechanism. See Proposal for a Directive of the European Parliament and of the Council on the promotion of the use of energy from renewable sources. they face due to external costs in the conventional energy sector.

8 L. Alagappan, R. Orans, and C.K. Woo, "What Drives Renewable Energy Development?" Energy Policy 39, no. 9 (2011): 5102.

9 Renewables 2016 Global Status Report (Paris: REN21 Secretariat, 2016), 20.

10 Toby Couture and Yves Gagnon, "An Analysis of Feed-In Tariff Remuneration Models: Implications for Renewable Energy Investment". Energy Policy 38 (2010): 955-957.

${ }^{11}$ Bürer and Wüstenhagen, 5002.

12 James Edward Aldridge, "The Role of the Small-Scale Feed-in Tariff in Electricity System Transition in the UK", (Ph.D. thesis, University of Exeter, January 2013), 241.

${ }^{13}$ ICSID Case No. ARB/13/36. The case was held in the International Centre for Settlement of Investment Disputes tribunal. The Spanish government violated Article 10 of the Energy Charter Treaty and depriving the rights of the power producers to fair and equitable treatment. The decision made was contrast with an earlier case in the Stockholm Arbitration Tribunal, in which Charanne B.V. and Construction Investments claimed for damages 
government are central to the development of RE in the country. The government of Spain introduced financial incentives for renewable energy via Royal Decree 661/2007 (RD 661/2007). Under this law, a steady subsidy system was founded that allowed power producers to enjoy guaranteed lucrative returns from the electricity generation whereby Eiser and Energia Solar participated in solar power projects. However, in 2013, a new law came into force, which repealed RD 661/2007. This amendment repudiated any benefit received by the power producers under fixed tariffs and premiums system and caused adverse impacts on solar power programs in Spain. The Tribunal ruled that Spain violated the rights of power producers, who were severely affected by the unilateral amendment to the law, and ordered Kingdom of Spain to pay a principal amount of $€ 128$ million.

In Malaysia, section 2 of the RE Act 2011 defined FiT as:

the special tariff payable to feed-in approval holders in consideration for renewable energy generated and sold to a distribution licensee as specified in the third column of the Schedule.

The landscape of the Malaysian' energy sector has become more complex, and the solar PV role has created a new impetus in supporting the country's energy aspiration. Through Solar PV, local actors and industries have continued upscale ${ }^{14}$ as the FiT policy is designed for small-scale RE generation of below 30MW. ${ }^{15}$ Before 2009, solar PV and other RE technology installation were far cry as evidenced in the collapsed projects under the Small Renewable Energy Programme (SREP). ${ }^{16}$ Despite the criticisms of FiT, the existence of local manufacturers in the solar PV industry has reflected the public acceptance of low carbon energy transition and is a catalyst for more $\mathrm{RE}$ technology installation and generation in the future. Furthermore, FiT and the RE Act 2011 have opened more doors for RE projects

from the government of Spain as a result of the termination of subsidies for photovoltaic power projects. The tribunal dismissed the claims.

14 Since the introduction of the RE Act 2011, RE generation, especially from solar PV, has increased tremendously.

15 Section 4 (a) of the Renewable Energy Act 2011 (Act 725).

16 Sovacool, Benjamin K., and Ira Martina Drupady. "Examining the small renewable energy power (SREP) program in Malaysia." Energy Policy 39, no. 11 (2011): 7244-7256. 
within the electricity market by creating 'protection' for power producers through Renewable Energy Power Purchase Agreement (REPPA). This approach will help overcome barriers in trading arrangements and the transmissions of supply. ${ }^{17}$ It also successfully addressed problems which emanated from the National Policy on Renewable Energy and Action Plan 2009.

In terms of delivering $\mathrm{RE}$ targets generation capacities within the national energy mix, FiT has been ineffective because the current RE generation capacity is not significant. Although FiT has provided a viable platform for establishing a RE market, other RE technologies such as biomass, biogas, mini-hydro and geothermal have yet to be significantly exploited. The authors argue that the FiT provides imbalanced progress regarding all RE technologies. This mechanism, thus, has failed to inspire diverse technology and attract enough investments. Moreover, other support policies are still required to cater for increasing demands in harnessing electricity from the sun, as evidenced in the issuance of guidelines for Large Scale Solar (LSS) and Net Energy Metering (NEM). From the financial lens, FiT alone is insufficient as a commercial policy. Other fiscal instruments are essential in reducing RE cost and driving towards a more competitive electricity market.

Although the insignificant contribution of other RE technologies is evident, due to some inherent deficient factors in the technology itself, some adjustments to the tariff rates and the digression level may be beneficial. However, this idea again triggers some associated financial risks. The consumers' contribution to the RE Fund through the electricity bill will increase, and the government will have to subsidise $\mathrm{RE}$ projects directly. It can be inferred from a clear manifestation of the government's strategy for not increasing the FiT quota for solar PV, that increasing the tariff rate is not desirable. It is submitted that solar PV, biomass and biogas power producers should be gradually exempted from the FiT programme and Place them under a new RE scheme where auctions can be implemented.

17 See Renewable Energy (REPPA) Rules 2011 P.U. (A) 386. 


\section{AUCTIONS AND THE TENDERING SYSTEM'S POTENTIALS}

The legal and institutional framework to support RE generation is critical for ensuring that the energy target in a country is achievable. Many countries seek to provide a viable policy, which will be able to keep up with energy demand and technological changes. Evidence has indicated that there are numerous issues in implementing FiT, especially in terms of cost. ${ }^{18}$ On the contrary, a study has suggested that FiT is superior when compared to other schemes, including auctions. It reduces costs, lowers risks and promotes competition among power producers. ${ }^{19}$ Nevertheless, to accelerate RE development and create a more sustainable energy sector, Malaysia will require special schemes such as auction with the ability to lower electricity costs and correspond with other existing RE support instruments.

$\mathrm{RE}$ auctions are also known as "demand auctions or procurement auctions, whereby the government issues a call for tenders to procure a certain capacity or generation of renewables-based electricity". Interested power producers who intend to participate in auctions have to submit a bid before the set deadline. Thereafter, assessments will be made on offer made, in line with several considerations and requirements, before the PPA is awarded. ${ }^{20}$ The United Kingdom (UK) is one of the earliest countries to introduce auctions through the NonFossil Fuel Obligation (NFFO) in the 1990s. ${ }^{21}$ Auctions were found to have assisted the UK's wind energy development, while also reducing costs of solar and ocean energies. ${ }^{22}$ However, several encumbrances

18 James Prest, "The Future of Feed-in Tariffs: Capacity Caps, Scheme Closures and Looming Grid Parity," Renewable Energy Law and Policy Review Vol. 3, No. 1 (2012): 26.

19 Lucy Butler and Karsten Neuhoff, Comparison of Feed in Tariff, Quota and Auction. Mechanisms to Support Wind Power Development (University of Cambridge, 2006), 31. (Quoted with permission).

20 Hugo Lucas, Rabia Ferroukhi and Diala Hawila, Renewable Energy Auctions in Developing Countries (Abu Dhabi, IRENA, 2013) 6. www.irena.org/Publications (accessed 30 January, 2018).

21 Ibid., 9.

22 Catherine Mitchell and Peter Connor, "Renewable Energy Policy in the UK 1990-2003," Energy Policy 32 (2004): 1941. 
occurred for the implementation of effective auctions for RE in the $\mathrm{UK}^{23}$

A growing number of countries have adopted this policy. Approximately 64 countries have deployed these mechanisms by the end of 2015, including several European countries with RE development using the tendering system. ${ }^{24}$ Indonesia was the first ASEAN country that deployed auctions for solar PV and geothermal sources in 2013; while Singapore embarked on its first pilot auction program for solar $\mathrm{PV}$ in 2015. ${ }^{25}$ Twenty-two countries held RE auctions in 2016 for various RE technologies, with solar PV ${ }^{26}$ dominating followed by wind energy. ${ }^{27}$ India had an auction for $1 \mathrm{GW}$ Solar PV, while Indonesia was the only country that held an auction for geothermal power for $680 \mathrm{MW}^{28}$

The new trends in the emerging RE sector have demonstrated that the world leader in RE technology, Germany has shifted to deploy auctions to spur its solar energy development. The Germany Renewable Energy Act 2017 (EEG 2017) was extensively amended through the introduction of a tendering system for most RE sources. This scheme will replace its predecessor i.e., the FiT mechanism, in accelerating RE generation at a much lower cost as it is evident that this scheme has stimulated competition and cost-effective to reduce the burden of the technology. Under the German experience, auctions were not only able to attract more participation but lead to inclined prices for

23 Peter M. Connor, "UK Renewable Energy Policy: A Review," Renewable and Sustainable Energy Reviews 65 (2003): 77.

24 Renewables 2016 Global Status Report (Paris: REN21 Secretariat, 2016), 20.

25 Sopitsuda Tongsopit, Wathanyu Amatayakul, Phoebe Grace Saculsan, Vu Hoang Nghia, C. Tirpornvitoon, Rémy Favre, and A. Afanador, Designing Renewable Energy Incentives And Auctions: Lessons For ASEAN (United States Agency for International Development, 2017) http://www.usaidcleanpowerasia.com/publications.html (accessed 21 November, 2017).

26 Approximately 18 countries were held and granted auctions for solar PV in 2016.

27 Approximately five countries were held and granted auctions for wind power in 2016.

28 Renewables 2017 Global Status Report (Paris: REN21 Secretariat, 2017), 206. 
the energy itself. ${ }^{29}$ Throughout this new transition, the German RE market is expected to be more responsive, grid expansion for RE would be is achieved and it lessen the burden for consumers to pay renewables-electricity. Other European countries such as Spain and Denmark have been working to implement similar mechanisms to promote RE and set a path for a market-driven renewable energy sector. These efforts are in line with the target of the European Commission (EC) to overcome the flaws of the FiT mechanism, to spur RE deployment and expansion of renewable-based grid within the EC. ${ }^{30}$

Several benefits of auctions and tendering system have been identified in terms of the framework, pricing quantity, transparency and cost-effectiveness. The first benefit is that the framework underlying this scheme is more flexible, as varied elements may be adapted to meet certain circumstances including economic, energy structure, market condition and RE generation capacity. Secondly, this scheme provides an advantage to the government to control the price and quantity of renewable electricity generated while also ensuring that the RE target is achieved. ${ }^{31}$ Furthermore, contracts under auctions contain specific provisions on the commitments and liabilities of the parties. Failure to abide by the contract will be met with penalties. Lastly, costeffectiveness is one significant benefit of auctions, as the actual cost of RE technology can be identified, and this phenomenon leads to the declining cost, especially in solar and wind projects. ${ }^{32}$ This was also supported by the result of the implementation of auctions under the South African RE programme which resulted in lower RE generation cost compared to the cost of coal generation. However, in Denmark, no clear evidence cost benefit in RE auctions. ${ }^{33}$

It is crucial to know the types of available auctions and factors contributing to successful RE projects. There are three commonly practised auction models, which include sealed-bid auctions,

29 Renewable Energy Auctions: Analysing 2016 (Abu Dhabi: IRENA, Abu Dhabi, 2017), 6.

30 Ibid.

31 Ibid., 8.

32 Ibid.

33 David Toke, "Renewable Energy Auctions and Tenders: How Good are They?" International Journal of Sustainable Energy Planning and Management vol 08 (2015): 53. 
descending clock auctions, and hybrid auctions. ${ }^{34}$ International Renewable Energy Agency (IRENA) has listed five factors in developing the auction system for RE, which includes types, ceiling prices, auction volumes, administrative procedures, and also guarantees and penalties. ${ }^{35}$ The successful bidding process and RE project are also contributed to by the effectiveness of the legal framework. Without a clear and compelling law for initiating RE auctions, all stages involved poses some difficulty in monitoring. In Morocco, auctions have commenced by the government for solar and wind energy, through the Renewable Energy Law 13-09 and the MASEN Law 57-09. ${ }^{36}$ Meanwhile, in Brazil, the Ministry of Energy and Mines (MME) and the Electricity Regulatory Agency (ANEEL) are responsible for conducting auctions processes, as detailed in the Laws 10847 and 10848 for wind, small hydro and biomass. ${ }^{37}$

Analysing the advantages of auctions has revealed the essential features for designing the Malaysian RE framework regime, and overcome the challenges of FiT. This scheme offers low risks investment, as the long-term power purchase agreement PPA provides guaranteed revenue and access to the grid. Most importantly, auctions drive vigorous competitions among RE developers, leading to the discovery of the floor price, which is not possible for any other RE support scheme. ${ }^{38}$ Besides, auctions are designed for a specific installed capacity, and convenient for managing all related expenditures beforehand. Through this scheme, electricity generation and supply can be correspondingly improved. Auctions also allow for effective control of project volume based on the available budgets for capital support. Another critical aspect of auctions is the awarded contract itself, as it navigates the progress of projects, including acquisition of new power capacities and identification of nonperforming projects.

More importantly, although the price offered is vital to winning bids, some auctioneers have indicated several requirements for bidders that would likely enhance local engagement and environment, while

\footnotetext{
${ }^{34}$ Lucas, Ferroukhi and Hawila, 42-43.

35 Ibid., 7.

36 Lucas, Ferriukhi and Hawila, 31.

37 Ibid., 19.

38 Ibid., 12.
} 
also supporting industry expansion. ${ }^{39}$ Apart from the price being the primary awarding criterion in auctions, other measures such as technological advancement and environmental issues are also evaluated. ${ }^{40}$

\section{AUCTIONS IN GERMANY}

As the world leader in RE industry, Germany provides an excellent example for many countries including Malaysia, which was well reflected in the Malaysia National Renewable Energy and Action Plan 2009. ${ }^{41}$ The Germany Energy Industry Act was enacted to enhance the supply and production of sustainable energy. ${ }^{42}$ One special characteristic of auctions in Germany is that the law and policy encourage the diversity of participation without being limited to largescale and broad portfolio RE developers. ${ }^{43}$ The amendments to the Renewable Energy Sources Act (EEG 2017) were made based on successful pilot auctions that were initiated since 2015. Although the auctions were also opened to other RE technologies like offshore wind, auctions for solar PV have resulted in the most diverse competition and have attracted a wide range of participation including small-scale power producers.

Other than local auctions, the EEG 2017 has also supported crossborder auctions for RE generation. ${ }^{44}$ The German and Danish governments have continued to initiate auctions for RE installations in both Germany and Denmark. Though preceding pilot auctions supported solar PV, Germany sought to extend the same for onshore

39 Lucas, Ferriukhi and Hawila, 13.

40 Jenni Lairila, "The Role of Small Actors in Renewable Energy Auctions", (Master thesis, Aalto University, 2016), 33.

41 Farahdilah Ghazali "Renewable Energy Law and Policy in Malaysia: A Critical Analysis", (PhD thesis, 2018, International Islamic University Malaysia): 271.

42 "Policies and Measures," International Energy Agency, https://www.iea.org/policiesandmeasures/pams/germany/name-22752en.php (accessed 31 January, 2018).

43 Lairila, 4.

44 Section 88a of the Renewable Energy Sources Act (EEG 2007) (Germany). 
wind. ${ }^{45}$ Auctions in Germany are regulated in Division 3 of the EEG 2017, offering an extensive coverage of RE technology installations including onshore wind, ${ }^{46}$ solar $^{47}$ and biomass. ${ }^{48}$ The arrangement of the volume of auctions can be found in section 28 , which indicates different volumes for each year from 2017 to 2020. This arrangement has developed a picture that auctions in Germany are meant for a massive scale of RE generation. However, a study shows that auctions were also designed to correspond with the needs of small-scale RE developers. ${ }^{49}$ The law also empowers the Federal Network Agency to announce matters related to the auctions on websites, including bid deadline, the auction volume, the maximum value, the information about laws enacted by land governments, and the format for bid submission. ${ }^{50}$

The Act further authorises the Federal Network Agency to execute guidelines for auction and bidding processes. Any bid should be submitted before the stipulated deadline. Any withdrawal of bids shall be commenced at least on the deadline, and a written form must be submitted accordingly. ${ }^{51}$ As a bid submitted to the agency, security shall be deposited, and the bidders are obliged to identify which bid the security is for explicitly. The security shall be preceded either through guarantee payment issued by a bank or a credit insurer, or a direct payment to the account of the Federal Network Agency. ${ }^{52}$ Aside from this, the Agency is permitted to increase or decrease the maximum

45 Beatrix Massig, "German Renewable Energy Law (EEG 2017) and CrossBorder Renewable Energy Tenders," www.irena.org (accessed 31 January, 2018).

${ }^{46}$ Section 36 of the Renewable Energy Sources Act (EEG 2017) (Germany).

${ }^{47}$ Section 37 and section 38 of the Renewable Energy Sources Act (EEG 2017) (Germany).

${ }^{48}$ Section 39 of the Renewable Energy Sources Act (EEG 2017) (Germany).

${ }^{49}$ Lairila, 53.

${ }^{50}$ Section 29 of the Renewable Energy Sources Act (EEG 2017) (Germany).

${ }^{51}$ Section 30a (1) (2) (3) of the Renewable Energy Sources Act (EEG 2017) (Germany).

${ }^{52}$ Section 31 (1) (2) (3) of the Renewable Energy Sources Act (EEG 2017) (Germany). 
values for the auctions pursuant to Section $85 a{ }^{53}$ However, the new value may not diverge 10 per cent from the previous maximum value. ${ }^{54}$

Apart from the EEG 2017, the Federal government was authorised to issue a specific ordinance to commence auctions for specific RE technology, with approval from the Bundesrat or German legislative body. The Federal Government has the right to issue rules on auctions for biomass, to regulate matters including breaking auction volume and setting the cost and the progression of auctions. ${ }^{55}$ Rules can also be made to monitor installation capacities and arrangements, to specify requirements and payment entitlements. ${ }^{56}$ They also establish requirements for participation in auctions. ${ }^{57}$ In conjunction with biomass installation, the Federal government is legally permitted to promulgate regulations concerning electricity generation from biomass. ${ }^{58}$ It may also entail environmental and sustainability requirements for biomass installation..$^{59}$

As mentioned earlier, EEG 2017 also made some provisions to regulate matters on conducting cross-border auctions. The Federal government is authorised to introduce rules to open installations in other EU countries. The rules shall contain issues on entitlement to pay for installations and the procedure and content of auctions. ${ }^{60}$ Besides, the law empowers the Federal Ministry for Economic Affairs and Energy to issue ordinances without the legislative or Bundesrat's approval, on matters relating to designing grid expansion area, ${ }^{61}$ and joint auctions for onshore wind and solar installations. ${ }^{62}$ In respect to innovation auctions, the Federal government is allowed to enact rules without the Bundesrat's approval if it will assist in meeting the

53 Read together with Section 36b, Section 37b or Section 39b and Section 29 of the Energy Industry Act.

54 Subsection 1.

55 Section 88 (1) of the Renewable Energy Sources Act (EEG 2017) (Germany).

56 Subsection 2.

57 Subsection 3.

58 Section 89 of the Renewable Energy Sources Act (EEG 2017) (Germany).

59 Section 90 of the Renewable Energy Sources Act (EEG 2017) (Germany).

60 Section 88a of the Renewable Energy Sources Act (EEG 2017) (Germany).

61 Section 88b of the Renewable Energy Sources Act (EEG 2017) (Germany).

62 Section 88c of the Renewable Energy Sources Act (EEG 2017) (Germany). 
requirements of the grid system or the system. ${ }^{63}$ However, the Act does not explicitly provide interpretations of innovation auctions. Section 97 (1) of the Act stipulates on the submission of progress reports for evaluating the Act, including matters connected to experience with auctions to the Bundestag starting on 30th June 2018. The report was proposed to be submitted every four years afterwards.

These provisions echo Germany's goals in creating sustainable energy and electricity sectors. This legislation aims to have two achievements, which are to produce sufficient energy to meet both present and future demands and also to develop alternative energy to resolve climatic issues. Germany, within the spirit of the EU, has also geared the new face of the Act by promoting regional cooperation among EU members on cross-border auctions. These efforts are aligned with the UN Charter in fostering international cooperation on matters relating to economic and social development. ${ }^{64}$ They are also aligned with the EU Renewable Energy Directive (2009/28/EC), which focuses on statistical transfers, joint projects and joint support schemes.

\section{RE AUCTIONS IN INDIA}

India has similar features to Malaysia, in terms of RE sources, geographical factors and economic growth. As of 2016, the GDP growth rates for India and Malaysia were 7.1 per cent for and 4.2 per cent respectively. Meanwhile, the GDP per capita as of 2016 is 1,709.39 USD for India, and 9,502.57 USD for Malaysia. ${ }^{65}$ Similar to Malaysia, India is in the middle of the transformation phase towards being an industrialised nation, and she has been working to become a prominent RE producer in the world. In 2015, India reached a fifth global ranking for solar power and wind power production. ${ }^{66}$ Although there is no specific law on auctions for RE projects in India, the uniqueness of the Indian legal system has permitted auctions to be

63 Section 88d of the Renewable Energy Sources Act (EEG 2017) (Germany).

64 Article 55 of the Charter of United Nations 1945.

65 The World Bank, https://data.worldbank.org/ (accessed 11 December, 2017).

${ }^{66}$ Economic Outlook for Southeast Asia, China and India 2017: Addressing Energy Challenges, (Paris: OECD Publishing, 2017), 138-139. doi:10.1787/saeo-2017-en. 9. 
implemented at the state level. Several states in India have successfully awarded auctions tender for among solar PV projects including the states of Gujarat Tender, Tamil Nadu, Karnataka and Andhra Pradesh. The country has created another milestone in RE development, mainly solar PV through auctions. The Indian government's Union Ministry of New Renewable Energy (MNRE) has announced a 2GW Pavagada Solar Park project- the world largest solar project which was completed in 2019. The objectives are to improve the local farmers' economy while providing clean energy to the states that lack access to the electricity grid. ${ }^{67}$ Prior to this project, India, with the government's aspirations to generate at least $40 \%$ of electricity from renewable sources by 2030, unveiled the GW Kurnool Ultra Mega Solar Park in Andhra Pradesh. ${ }^{68}$ However, auctions in India are not limited to large scale RE projects. Some small-scale solar projects, for instance with the capacity of $1 \mathrm{MW}$ to $5 \mathrm{MW}$, have been held under the Indian National Solar Mission.

In India, auctions are superior to FiT, in terms of cost-effectiveness and allocation equity. Auctions offer tariff reductions of up to $58 \%$ in the case of solar PV auctions and up to $30 \%$ in the case of wind auctions. Other studies show that intangible costs will most likely increase in the future, in contrast with FiT-based projects. ${ }^{69}$ Moreover, with respect to equity in allocation, auctions have been significantly directed to the reasonable distribution of projects in which vast participation is encouraged..$^{70}$ In terms of effective deployment, only $25 \%$ of auctions can pull off the capacity requirements successfully. These failures also affected to FiT based projects along with poor project management practices. $^{71}$ Poor management attributes were

67 Sophie Vorrath, "A 2GW Solar Farm - For Farmers: India Launches "World's Largest Solar Park," Renew Economy, http://reneweconomy.com.au/2gw-solar-farm-farmers-india-launchesworlds-largest-solar-park-11603/ (accessed 27 March 2018).

68 V. Rishi Kumar, "Global Focus on Kurnool Solar Park," The Hindu Business Line, https://www.thehindubusinessline.com/news/national/global-focus-onkurnool-solar-park/article9945725.ece (accessed 27 March 2018).

69 Gireesh Shrimali ,Charith Konda, and Arsalan Ali Farooquee, "Designing Renewable Energy Auctions for India: Managing Risks to Maximize Deployment and Cost-Effectiveness . Renewable Energy 97 (2016): 661.

70 Ibid., 662.

71 Ibid. 
inherited from several risks, including project risks that have had more significant impacts when compared to auction-specific risks. ${ }^{72}$ Therefore, with an effective risk management and well-designed auctions, these issues are surmountable. ${ }^{73}$

Guidelines for Implementation of Scheme for Setting up of over 5000 MW Grid-connected Solar PV Power Projects under Batch-IV, is one of the guidelines issued by the Indian Ministry of New and Renewable Energy (MNRE) in 2016 to regulate competitive bidding for solar PV projects. ${ }^{74}$ The Solar Energy Corporation of India (SECI) is responsible for implementing this scheme, which is projected to provide at least 5,000 MW Grid-connected Solar PV power projects. ${ }^{75}$ Accordingly, the MNRE will offer no financial assistance to SECI in carrying out the activities under these guidelines. ${ }^{76}$ However, the State Level Agency will be appointed to facilitate matters related to approval and sanctions, so that the commissioning projects could be completed within the stipulated duration. ${ }^{77}$ As for connecting the project with the grid, State Transmission Utility will run the transmission system. ${ }^{78}$ Meanwhile, the Solar Park Implementation Agency (SPIA) is responsible for assisting in establishing and implementing the Solar Park in the Host State. ${ }^{79}$ The Empowered Committee under the chairmanship of Joint Secretary, on the other hand, shall recommend fixing the tariff for the purchase of solar power by SECI, as well as proposing amendments to the guidelines for improved implementation. ${ }^{80}$

72 Ibid., 664.

73 Ibid., 665.

74 Guideline no. 1.3.3 of the Guidelines for Implementation of Scheme for Setting up of over 5000 MW Grid-connected Solar PV Power Projects.

75 Guideline no. 1.3.1 and no. 1.4. Ministry of New and Renewable Energy, https://mnre.gov.in/file-manager/UserFiles/Guidelines-for-5000MW-

Grid-Connected-power-project-under-VGF-NSM.pdf. (accessed 3 February, 2018).

76 Guideline no. 1.4 of the Guidelines for Implementation of Scheme for Setting up of over 5000 MW Grid-connected Solar PV Power Projects.

77 Guideline no. 4.1.

78 Guideline no. 4.2.

79 Guideline no. 4.3.

${ }^{80}$ Guideline no. 4.4. 
Throughout this scheme, competition between developers is welcomed, helping to enhance transparent e-bidding and e-auctioning processes. This method also assists in expanding solar PV deployment in India, complementing the existing grid power as well as mitigating high costs in the transmission system. ${ }^{81}$ These guidelines also further enumerate the qualifications criteria for short-listing projects, which include financial, technical and connections to the grid. ${ }^{82}$ Guideline no. 3.11 indicates a standard Power Purchase Agreement (PPA) for the sale and purchase of power by SECI, at a tariff set by the MNRE for 25 years, while SECI shall sell the power to state utilities or any other entity for 25 years. The bidders are required to submit bank guarantees to SECI, through manners indicated in guideline no. 3.12, while competitive reverse bidding will be embarked on to select the projects.

While auctions for RE have been initiated at both central and state levels, these have attracted legal uncertainty and dispute. The Renewable Energy Law 2015 has been passed, while RE, especially wind energy, has rapidly expanded in India. Despite the need for RE, the deployment of auctions for supporting wind energy has been criticised. This issue was exhibited in the case of Indian Wind Energy Association vs Gujarat Urja Vikas Nigam Ltd (GUVNL) \& Ors. No (S) 20922 of 2017. Auctions were seen as a threat to the wind technology industry by small-scale manufacturers in the industry, due to the significant reduction of wind energy tariff. The petitioner argued that the wind bidding process is ultra vires of existing provisions, namely Section 62 of the Electricity Act 2003 and Section 6.4 (2) of the National Tariff Policy 2016. Section 6.4(2) of the National Tariff Policy 2016 specifies that: "States shall endeavour to procure power from renewable energy sources through competitive bidding to keep the tariff low, except from the waste to energy plants".

Section 62 of the Electricity Act 2003 has elaborated on the duty of the Appropriate Commission, and requirements to determine the tariff for electricity supply. However, in the case of auctions, the determination of the tariff is subject to Section 63 of the same Act, which specifies that tariff has been determined through a transparent process of bidding in accordance with the guidelines issued by the Central Government. Although auctions were commenced as auspices

${ }^{81}$ Guideline no. 1.5.2.

82 Guideline no. 3.7. 
to wind energy's expansion in India, a proper legal framework is vital for maintaining its legality. As per section 63 of the Electricity Act 2003, it is lamentable to contemplate auctions for wind energy as being illicit under the law. On the other side, the presence of legal action has encouraged the Indian Minister of Power to pass a resolution on Guidelines for Tariff Based Competitive Bidding Process for Procurement of Power from Grid Connected Wind Power Projects on December 8, 2017. These guidelines provide a transparent framework for commencing competitive bidding for wind, as well as assisting the country in achieving a 60 MW power capacity from wind by 2022 .

\section{FEED-IN TARIFF AND AUCTIONS PRACTICES IN OTHER JURISDICTIONS}

Both FiT and auctions have their strengths and weaknesses; some countries have adopted both FiT and auctions in a complementary way. Auctions in China have been well established since 2003, primarily serving to accelerate the development of wind energy, and aiming to support a large-scale RE project. This scheme has brought down prices and has driven a market-based approach to identify the ceiling price for RE technology. ${ }^{83}$ Interestingly the Chinese Renewable Energy Law 2006 has empowered the government to fix the tariff for electricity generated from RE, by conferring prices determined through auctions. ${ }^{84}$ These auctions are technology-specific, focusing on determining the standard FiT for onshore wind and solar PV. ${ }^{85}$

Another country that has implemented a similar mechanism is Italy, through the Italian Regulatory Authority for Electricity Gas and Water (AEEG). A capacity cap was placed for each RE technology to incentivise RE projects without adding extra costs to the FiT scheme, except for solar. In order to access RE FiT, developers or power producers have to take part in reverse auctions, in which access to FiT will only be awarded to the lowest price offered. Through the blend of

${ }^{83}$ Rabia Ferroukhi, Diala Hawila, Salvatore Vinci and Divyam Nagpal., Renewable Energy Auctions - A Guide to Design, (IRENA and CEM, 2015), 19.

${ }^{84}$ Lucas, Ferroukhi, and Hawila, 24.

85 Ibid., 25. 
approaches, the competition among the bidders has driven up reductions of tariffs, especially for onshore wind projects. ${ }^{86}$

Ferroukhi et al. indicated that small-scale RE projects are most likely to benefit less from auctions. This problem is due to auctions being a competitive bidding atmosphere in which floor pricing of RE technology will indirectly destroy small RE industries. Knowing the fact that small RE developers are hardly able to stand out with major competitors, some countries still use FiT for small-scale RE projects, while auctions were executed for medium to large scale RE projects. This idea was reflected in the French solar PV policy, in which a smallscale project with an installed capacity of less than $100 \mathrm{~kW}$ is eligible to participate in the FiT program. Awarding processes for RE projects with installed capacities of more than $100 \mathrm{~kW}$ requires much simpler bidding processes when compared to projects with installed capacities of more than $250 \mathrm{~kW} .{ }^{87}$ However, each country may adopt different calculations, for classifying the scale of installation capacities for RE projects.

Notwithstanding the presence of criticism that auctions deprive small-scale projects; some countries have successfully executed auctions for small-scale projects, through effective cost management. ${ }^{88}$ Again, a closer look must be given to the actual installation or generation capacity of specific projects. In the case of France, projects with less than $100 \mathrm{~kW}$ are classified as small-scale projects while Uruguay defines small-scale projects without a total of less than 5MW. Therefore, solely relying on the category itself is not the critical determinant for successfully implementing auctions. An Amalgamation between FiT and auctions, either through the implementation of both mechanisms on the same project is possible as practiced in China and Italy. In certain situations, differentiating between these two mechanisms based on project scales requires further amendments to existing law and policy to guarantee the transparency and efficiency of price discovery. This also has the advantage of accelerating RE generation, especially for the electricity sector. Hence, a clear line must be drawn in categorising the scale of the project so that small RE developers' rights and privileges are protected.

\footnotetext{
${ }^{86}$ Lucas, Ferroukhi, and Hawila, 20.

87 Ibid., 21.

${ }^{88}$ Lucas, Ferroukhi, and Hawila, 21
} 


\section{AUCTIONS FOR RENEWABLE ENERGY DEVELOPMENT IN MALAYSIA: A WAY FORWARD}

Renewable energy auctions have been introduced in Malaysia via a Large-Scale Solar (LSS) Photovoltaic Plant Programme. Section 50C of the Electricity Supply Act 1990 (Act 447) empowers the Energy Commission (EC) to issue guidelines on a Large Scale Solar Photovoltaic Plant for Connection to Electricity Networks. The competitive bidding process under these guidelines involves a prequalification process for selecting bidders and project locations. The bidder is also required to submit a technical and commercial proposal, aligned with the commissioning project. Apart from that, some evaluation criteria will be taken into account in regards to the inclusion of compliance with technical and regulatory standards, financial capability, the practicality of project execution, and other factors. ${ }^{89}$ The target capacity for the whole of Malaysia is 1000 MW by $2020 .{ }^{90}$ The Energy Commission is empowered to review the annual target capacity periodically. ${ }^{91}$

One of the critical requirements for selecting bidders is that such company must be a "local company of which the Malaysian equity interest in such company is at least $5 \%$ or a consortium of legal entities which includes a minimum of one local company and which has a Malaysian equity interest in the consortium of at least 51\%". Another essential feature is that the utilisation of land for commissioning projects is not limited to one purpose, and as such, other economic activities are highly encouraged. After the proposal's submission, the Energy Commission Board will evaluate and grant a Conditional Letter of Award to the successful bidder, before entering into the power purchase agreement (PPA) negotiation stage. Similar to FiT, PPA for LSS offers a long-term contract of 21 years. ${ }^{92}$ The bidders also have to

89 Guidelines no. 5 of the Guidelines on Large Scale Solar Photovoltaic Plant For Connection to Electricity Networks.

90 Guidelines no. 6.

91 Guidelines no. 7.

92 Guidelines no. 8. 
obtain land or submit a certified Lease Agreement of the land, as well as acquiring the Right of Way (ROW) and relevant permits. ${ }^{93}$

It was expected that the construction of solar farm will commence a year after the PPA is signed. Before construction, the power producer needs to submit the conceptual design report to the facility, with a certified copy of the Environment Impact Assessment (EIA) approval, and other required documents to the distribution licensee and the Energy Commission. Once the project is initiated, a certified copy of the Initial Financing Project Documents and the Project Documents to the distribution licensee and the EC will be prepared. Despite the existing guidelines for solar PV, the new face of auctions design should be crafted in order to offer diverse technologies at the lowest price, while also assimilating this scheme into the RE Act 2011. It is also crucial to learn from best practices in other jurisdictions, in addressing prevalent challenges to successful RE auctions.

India and Germany have embarked on different approaches to arranging technology auctions. India is keen on promoting solar PV and on developing a large-scale solar farm, therefore adopting technology-specific auctions. However, India has not abandoned other technologies but rather has simultaneously encouraged competition among technologies. For instance, wind power was found to be the cheapest energy source in that country, due to decline patterns in auction tariffs. ${ }^{94}$ In the Malaysian context, technology-specific auctions may suit local circumstances by focussing on auctions on solar PV, biomass and biogas. Malaysia's solar PV industry has matured and progressed well, whereas biomass and biogas are still developing and have bright prospects, with a variety of sources available for conversion into energy. Therefore, this auction arrangement may be beneficial in a way that supports the advancement of technology, subsequently lowering its cost.

Several factors are essential for guaranteeing successful RE auctions. The first factor that contributes to their success is effective coordination through a specific governing body that regulates all

93 Guidelines no. 11.

94 Bhanvi Arora, "Wind Power is Now The Cheapest Energy in India," Bloomberg

Quint.

https://www.bloombergquint.com/business/2017/12/21/wind-power-isnow-the-cheapest-energy-in-india (accessed 29 March 2018). 
matters on the auctions process, as well as to project progress. ${ }^{95}$ Secondly, fiscal support from government and financial institutions is essential to reduce costs and accelerate project development. ${ }^{96}$ Lastly, the existence of penalties for the non-delivery of projects, or noncompliance with any terms of the contract is critical to ensure certainty of the project. ${ }^{97}$ The penalty provision should be incorporated into the Act to reduce the risk of infringement. In the case of breach of contract, legal actions taken may result in the imposition of financial penalties or other consequences to developers.

The current RE Act 2011 make room only for the implementation of FiT as a catalyst for RE generation projects below 30MW. Thus, new legislation or amendment to the RE Act 2011 are needed for renewable energy projects to be applied to the matured RE technologies such as solar power plants with installed capacity exceeding $30 \mathrm{MW}$. The new law or provisions should reflect the IRENA's guidelines, including reputation requirements, technological requirements, production site selection and documentation, instruments to promote socio-economic development, and grid access security. ${ }^{98}$ Guaranteed access to the electricity grid is indispensable when warranting a viable auctions framework for RE generation ${ }^{99}$. The proposed reform which the Act will undertake involves the formation of auctions for RE deployment, which should be complemented in the Renewable Energy Act 2011. The author is of the view that these changes will have a direct impact on RE development in Malaysia.

\section{CONCLUSION}

As discussed earlier, auctions may not benefit small-scale RE developers, especially when they involve competitive bidding for large-scale projects. Competitive bidding also reduces the cost of RE generation and administrative cost of the government to a level that a small-scale RE projects are unable to make profits. Therefore, specific RE auctions goals should be defined, and the framework of the auctions

95 Toke, 52.

96 Ibid., 49.

97 Ibid., 53.

98 Ferroukhi, Hawila, Vinci, and Nagpal, 11.

99 Lucas, Ferroukhi, and Hawila, 21. 
should be designed to suit these goals. By allowing small-scale developers to participate, this will increase public acceptance of RE projects, enhance the national RE portfolios and project distribution, and maintain grid viability. On the other hand, the public may not be able to enjoy a minimum price. In most cases, auctions for solar PV suit small-scale developers, which can be compared to wind energy projects. ${ }^{100}$ However, in the Malaysian context, as a study suggested that Malaysia has few potential sites to build a wind farm and be suitable for small-scale generation, auctions may not be viable schemes for supporting development. ${ }^{101}$ On the contrary, a technology-specific auction could also introduce the least developed and most expensive RE technology. ${ }^{102}$

Nevertheless, FiT is still needed to introduce new RE technologies, such as wind and tidal. Therefore, FiT should not be removed entirely from the current RE law, due to the effectiveness of regulatory measures to establish new RE technology, ${ }^{103}$ to support the electricity sector, and to benefit small-scale RE generation projects. ${ }^{104}$ The authors are of the opinion that a new design of FiT should be constructed, by assigning financial obligations to private entities, while the government remains as a regulator. ${ }^{105} \mathrm{~A}$ periodical review is required to assess this effectiveness and responsiveness of this approach using electricity price as a guide. ${ }^{106} \mathrm{~A}$ broader scope of the existing RE Act is necessary for echoing the balanced interest of the name of the Act itself. Indeed, the wording of the long title of the Act circumvents the incorporation of other RE support mechanisms, including auctions under the Act. To maintain and further encourage

\footnotetext{
${ }^{100}$ Ibid.

${ }^{101}$ Aliashim Albani., "Wind Energy Assessment for Selected Sites in Malaysia and the Proposed feed-in tariff rates," (Master thesis, Universiti Malaysia Terengganu, 2013), 109-110.

102 Riccardo Fagiani, "Market-Based Support Schemes for Renewable Energy Sources (Master thesis, Politecnico di Milano, 2014), 6.

${ }^{103}$ Greg Buckman, "Renewable Electricity Support Policy: Lessons for Australia from Overseas Experience", (Ph.D. thesis, Australian National University, May 2011), 271.

${ }^{104}$ Aldridge, 241.

${ }^{105}$ Sara Emanuelsson "Feed-in Tariffs for Renewable Energy and the WTO Agreement on Subsidies and Countervailing Measures: Are Feed-in Tariffs Specific Subsidies?", (Master thesis, 2015, University of Gothenburg): 63. ${ }^{106}$ Buckman, 271.
} 
RE sources exploitation, the government should incorporate other RE support schemes, such as auctions into the existing Act. 